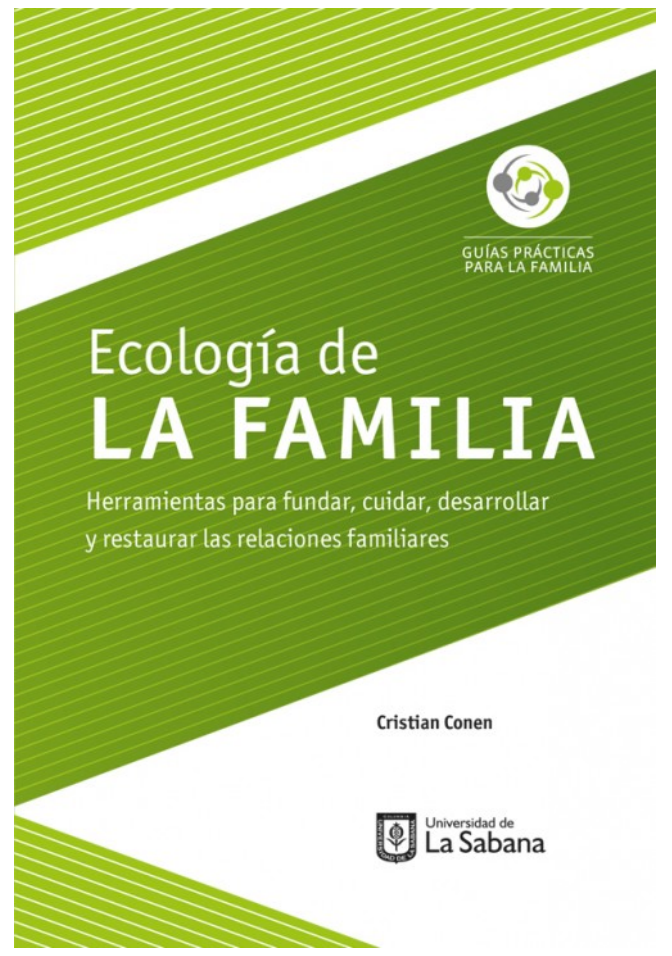

\title{
ECOLOGÍA DE LA FAMILIA \\ HERRAMIENTAS PARA FUNDAR, CUIDAR, DESARROLLAR Y RESTAURAR LAS RELACIONES FAMILIARES
}

Por: Cristian Conen

Formato: Impreso

ISBN: 978-958-12-0463-2

Facultad: Instituto de la Familia

Colección: Guías prácticas para la Familia

DOI: https://doi.org/10.5294/978-958-12-0463-2

Idioma: Español

Precio en dólares: USD $\$ 9,00$

Número de páginas: 100

Palabras clave: Amor, $\underline{\text { Cónyuges, Ecología humana, }} \underline{\text { Familia }}$

\section{$\$ 25.000$}

\section{Reseña del Producto}

El término ecología significa "conocimiento" y "cuidado de la casa". Hasta ahora se ha reducido el concepto al conocimiento y cuidado de la casa física: el planeta (aire, agua, fauna, flora, residuos, ruidos). Sin embargo, es tiempo de extender el significado de la ecología a la protección del ambiente humano óptimo para las personas. Ese hábitat ecológico personal es aquel en el que el ser humano recibe valoración y amor incondicional (no condicionado a las competencias profesionales, las destrezas deportivas o la simpatía, criterios estos de valoración en el mundo profesional, deportivo o social, respectivamente). En la familia nos valoran de forma incondicional por lo que somos y no por lo que hacemos o tenemos.

\section{Información Adicional}

\author{
Peso: $1 \mathrm{~kg}$
}

Tamaño: $17 \times 24 \times 2 \mathrm{~cm}$

Sku: 9789581204632

Código topografico: 306.8

\section{Tabla de contenido}

\section{INTRODUCCIÓN}

¿QUÉ ES LA ECOLOGÍA HUMANA?

¿QUÉ ES LA ECOLOGÍA DE LA RELACIÓN HOMBRE-MUJER?

Primera herramienta: ¿cuál es la unión hombre-mujer sólida?

Segunda herramienta: ¿cómo construir una unión hombre-mujer sólida?

Tercera herramienta: ¿cómo mantenerse los cónyuges enamorados?

Cuarta herramienta: ¿cómo superar obstáculos en la vida conyugal?

Quinta herramienta: ¿cuál es la gran ayuda conyugal espiritual?

Sexta herramienta: ¿cómo restaurar la relación conyugal? 
¿QUÉ ES LA ECOLOGÍA DE LA RELACIÓN PADRES-HIJOS?

Séptima herramienta: ¿cuáles son las claves para educar a los hijos?

Octava herramienta: ¿cómo educar para el amor sólido?

Novena herramienta: ¿cómo educar para la paz?

Décima herramienta: ¿cuál es el estilo educativo familiar óptimo?

CONCLUSIONES 89

REFERENCIAS 